\title{
Karolina Kolanowska
}

(iD https://orcid.org/0000-0001-7827-9134

Biblioteka Jagiellońska

Kustosz i samotnik. Tom poświęcony pamięci Romana Aftanazego, red. Adolf Juzwenko, Wydawnictwo Ossolineum, Wrockaw 2017, 272 ss.

Włodzimierz Roman Aftanazy, a wcześniej Aftanaziw¹, urodził się 2 kwietnia 1914 r. na terenie Galicji Wschodniej, w Morszynie-Zdroju, jako syn urzędnika kolejowego. Jego rodzice Jan i Olimpia prawdopodobnie byli małżeństwem mieszanym, polsko-ukraińskim, bądź ukraińskim. Aftanazy był abiturientem gimnazjum w Stryju, a następnie studentem Uniwersytetu Jana Kazimierza we Lwowie. Wybuch II wojny światowej przerwał Aftanazemu formalną naukę. Studia kontynuował na tajnych kompletach, które ukończył obronionym egzaminem w 1942 r. Na jego podstawie w 1946 r. na Wydziale Humanistycznym Uniwersytetu i Politechniki Wrocławskiej uzyskał tytuł magistra historii. Roman Aftanazy swoją pierwszą pracę zawodową otrzymał w Zarządzie Zdrojowym w Morszynie, początkowo jako pracownik fizyczny, a później umysłowy.

Przełomowym momentem w jego życiu stała się przeprowadzka do Lwowa, gdzie w 1944 r. podjął wolontariat w Bibliotece Zakładu Narodowego im. Ossolińskich, kierowanym przez prof. Mieczysława Gębarowicza. Swoje doświadczenie zawodowe Aftanazy zdobył przy opracowywaniu druków najnowszych. Udzielał się także przy zabezpieczaniu zbiorów bibliotecznych po bombardowaniu w $1944 \mathrm{r}$. Z początkiem

1 Według Tadeusza Epszteina Aftanazy porzucił w 1948 r. rosyjskobrzmiące imię Włodzimierz, na rzecz drugiego imienia Roman - zob. T. Epsztein, Nieznane fakty z biografii Romana Aftanazego (1914-2004), „Studia Dziejów Rosji i Europy Środkowo-Wschodniej” 2015, t. 50, z. 2, s. 108-109. 
sierpnia 1944 r., z chwilą przekształcenia Zakładu w Lwowską Bibliotekę Akademii Nauk Ukraińskiej Socjalistycznej Republiki Sowieckiej, Aftanazy został zatrudniony na stanowisku bibliotekarza. Zyskał uznanie samego dyrektora Gębarowicza, stając się jego „pieszczoszkiem” (dokładniej „pieszczoszek kustosza naszego” [tj. Gębarowicza], cyt. z listu M. Luftowej, 29 I 1949, Oss. 17147, s. 30). Po aresztowaniu Aftanazego przez Narodnyj Komissariat Gosudarstwiennoj Biezopasnosti (NKGB) za rzekome prowadzenie działalności antysowieckiej oraz dążenie do oderwania Lwowa od ZSRS, to właśnie dzięki poręczeniu przez Gębarowicza został zwolniony z aresztu.

W dalszych latach swojego życia Roman Aftanazy swoją postawą obywatelską wykaże wdzięczność za okazaną pomoc. Z chwilą gdy w Bibliotece Ossolineum za sprawą władz USRS dokonywano rozparcelowania zbiorów na rzecz narodu ukraińskiego, dyrektor Gębarowicz wraz z zaufanymi pracownikami, w tym również Romanem Aftanazym, podjął ryzyko przetransportowania do Polski niezinwentaryzowanych zbiorów. Aftanazy przewiózł i zdeponował w Bibliotece Jagiellońskiej w Krakowie komplety lwowskich tajnych pism z okresu wojny: „Słowa Polskiego” i „Wytrwamy”.

Nowa sowiecka władza przywłaszczyła sobie Lwów, a wraz z nim większość znajdujących się na jego terenie polskich dóbr kultury. Roman Aftanazy do 15 czerwca 1946 r., podobnie jak tysiące obywateli, musiał zmierzyć się z decyzją o wyjeździe lub pozostaniu we Lwowie. Społeczność polska pod naporem silnych represji poddała się przymusowej emigracji albo zdecydowała się przyjąć sowieckie obywatelstwo. W kwietniu 1946 r. Roman Aftanazy odebrał kartę ewakuacyjną. Z Polaka, obywatela Lwowa, stał się - jak sam notował w swoim Pamiętniku lwowskim - cudzoziemcem we... Lwowie (s. 143).

Nowy etap w życiu rozpoczął we Wrocławiu. W czerwcu, podobnie jak jego znajomi ze Lwowa, został zatrudniony w Bibliotece Uniwersyteckiej. W nowej instytucji Aftanazy został oddelegowany do repatriacji zbiorów Ossolineum przekazanych przez stronę sowiecką. W $1948 \mathrm{r}$. podjął pracę w reaktywowanym we Wrocławiu Ossolineum. Wraz z nominacją na kustosza objął kierownictwo Działu Gromadzenia i Uzupełnienia Zbiorów. Sprawował nad nim pieczę przeszło trzydzieści lat, aż do przejścia na emeryturę, tj. w $1981 \mathrm{r}$.

Roman Aftanazy dzięki staraniom swoim oraz współpracowników doprowadził do znacznego wzrostu kolekcji bibliotecznych. Już w latach 70. wrocławskie zbiory zostały uzupełnione o najważniejsze publikacje naukowe wydane przed $1939 \mathrm{r}$. W okresie stalinowskim nabywanie zbiorów nieodpowiadającym obowiązującej doktrynie wiązało się z dużym ryzykiem, łącznie z zarzutami o zajmowanie „, antyludowego stanowiska". Rekompensatą dla Aftanazego były oceny pracowników naukowych, którzy wyrażali pogląd, że zbiory Biblioteki Ossolineum we Wrocławiu stoją na takim samym poziomie, co zbiory Biblioteki Jagiellońskiej.

Emerytura nie przerwała jego pracy zawodowej w bibliotece. W niepełnym wymiarze godzin jako pracownik „do wszystkiego” (s. 40) Aftanazy wspomagał Dział Gromadzenia Zbiorów aż do końca 1987 r. Obok pracy zawodowej w bibliotece, kontynuował swoją największą pasję - dokumentował świat kultury ziemiańskiej na dawnych wschodnich ziemiach Rzeczypospolitej. Fascynacja dworkami kresowymi zna- 
lazła swój początek w latach dziecięcych, w trakcie pobytu na Polesiu. Opisy obiektów, które udało mu się zobaczyć, umieszczał w prasie, m.in. w: „Dodatku Naukowo-Literackim IKC”, „Światowidzie” oraz „Asie”. Po osiedleniu się we Wrocławiu powrócił do swojej pasji, poszerzając zakres dokumentacji o XIX- i XX-wieczne zamki, pałace i dwory usytuowane na terenie ziem wschodnich od Dźwiny po Dniestr i Dniepr.

W trudnych politycznych czasach źródłem informacji, oprócz bibliotek, archiwów i muzeów, stawała się korespondencja Aftanazego adresowana do właścicieli rezydencji i członków ich rodzin, a wraz z nią dołączany do niej szczegółowy kwestionariusz. Aftanazy zapytywał w nim m.in. o dzieje miejscowości, historię budowli, wyposażenia czy zbiorów bibliotecznych i artystycznych. Kilkadziesiąt tysięcy listów, pisanych prawie codziennie przez czterdzieści lat, częstokroć pozostawało bez odpowiedzi. Pomimo wielu trudności, Romanowi Aftanazemu udało się zgromadzić materiał, dzięki któremu mógł przystąpić do jego całościowego opracowania. Niepewny wartości własnej pracy i strachu przed brakiem zainteresowania tematem, opóźniał wydanie pierwszego tomu. W $1956 \mathrm{r}$. obawy Aftanazego niejako potwierdzily się. Wydawnictwo Ossolineum odmówiło publikacji pracy z racji „niewygodnej” tematyki ziemiańsko-kresowej. Na ich wydanie trzeba było czekać trzydzieści lat. Inicjatywę podjęli pracownicy Instytutu Sztuki PAN, na czele z prof. Stanisławem Mossakowskim, Ryszardem Brykowskim, Jerzym Malinowskim oraz mecenasem kultury dr. Andrzejem Ciechanowskim, fundatorem finansowym projektu. Całość Materiałów do dziejów rezydencji, jedenastotomowego dzieła w 22 woluminach, wydano w latach 1986-1993². Jeszcze przed ukończeniem druku zapoczątkowanym przez Instytut Sztuki, reedycją publikacji Romana Aftanazego zajęło się Wydawnictwo Zakładu Narodowego im. Ossolińskich. Drugie wydanie ukazało się w większym nakładzie, z ulepszoną szatą edytorską i pod bardziej precyzyjnym tytułem - Dzieje rezydencji na dawnych kresach Rzeczypospolitej ${ }^{3}$.

W swym opus magnum Aftanazy zawarł informacje na temat około 1500 obiektów: dworów, zamków, pałaców, przedstawiając ich historię, genealogię właścicieli, opisy architektoniczne rezydencji czy wyposażenia. Za swe wyjątkowe dzieło był wielokrotnie nagradzany i wyróżniany, m.in. Nagrodą Naukową Polskiej Akademii Nauk (1990), nagrodą Ministerstwa Kultury i Sztuki i Stowarzyszenia Konserwatorów Zabytków (1990), prestiżową Nagrodą Fundacji na Rzecz Nauki Polskiej (1994), a pośmiertnie nagrodą Kustosza Pamięci Narodowej przyznaną przez Instytut Pamięci Narodowej (2014).

Ziemie wschodnie pozostawały dla Romana Aftanazego nie tylko terenem badań, ale prawdziwym krajem rodzinnym, do którego po przymusowej emigracji nie zdołał już powrócić. Kontynuował długoletnią korespondencję ze swoim dawnym przełożonym, wciąż mieszkającym we Lwowie Mieczysławem Gębarowiczem, niejednokrotnie odwdzięczając się dawnemu zwierzchnikowi wsparciem i pomocą.

\footnotetext{
2 R. Aftanazy, Materiały do dziejów rezydencji, t. 1-11, Warszawa 1986-1993.

3 Idem, Dzieje rezydencji na dawnych kresach Rzeczypospolitej, t. 1-11, Wrocław 1991-1997.
} 
We wrocławskiej bibliotece przywoływał lwowską atmosferę i kresowe wartości. W określeniu jego osoby powtarzają się słowa: taktowny, sumienny, skrupulatny, obowiązkowy, daleki od sporów i dyskusji. Poczucie „duchowej” wspólnoty łączyło go z pracownikami oraz osobami wywodzącymi się z lwowskiego środowiska, reprezentującymi podobne wartości życiowe. Z nowymi kolegami, jak sam pisał, miał mało wspólnego, pozostawali dla niego często obcymi ludźmi (s. 35). Nie bez kozery Romana Aftanazego nazywano samotnikiem. Swój wolny czas w pierwszych latach po osiedleniu się we Wrocławiu wypełniał skrupulatnie zorganizowanymi wędrówkami po Dolnym Śląsku, które to być może, umocniły go w powrocie do przedwojennych zainteresowań. Z racji trudnej atmosfery politycznej swoje zamiłowania utrzymywał w tajemnicy. Dla własnych badań wykorzystywał wyłącznie swój czas poza pracą oraz własne skromne środki finansowe.

Z okazji dwusetlecia istnienia Zakładu Narodowego im. Ossolińskich, przypadającego na rok 2017, wydawnictwo Zakładu Narodowego im. Ossolińskich wydało księgę pamiątkową ku czci Romana Aftanazego. Pamiątkowy tom, rozpoczynający się Wstępem Adolfa Juzwenki, podzielony został na cztery części. Pierwsza z nich zawiera szkic biograficzny Włodzimierza Romana Aftanazego skreślony przez Macieja Matwijowa.

Szczególnie interesująca jest część druga tomu. Znajdujemy tam wykonaną przez Agnieszkę Knychalską-Jaskulską edycję Pamiętnika lwowskiego Aftanazego, pisanego od początku 1945 r. do kwietnia 1946 r. Autor zrelacjonował w nim m.in. pobyt w więzieniu i wyjście na wolność, sytuację polityczną sowieckiej Ukrainy, codzienność mieszkańców Lwowa, w tym także relacje między Polakami a ludnością napływającą ze Wschodu, kwestię ewakuacji biblioteki Ossolineum czy wymiany „dóbr kultury" Polską a ZSRS. W swoich zapiskach nie szczędził krytycznych uwag na temat polityki międzynarodowej. Z Pamiętnika Aftanazego wyłania się obraz miasta ulegającego dewastacji, w tym m.in. elementów przestrzeni miejskiej, skwerów, pomników kultury i instytucji. Przywołanie zapiski wspomnieniowe Romana Aftanazego ukazują też nastroje wśród ludności powojennego Lwowa. Ich autor opisywał nadzieje na powrót Lwowa do Polski, strach podsycany przez rządzące organa władzy albo podporządkowanie, które wyrażało się porzucaniem katolicyzmu i przechodzeniem na prawosławie.

W drugiej części tomu zamieszczono także wybrane listy Romana Aftanazego z lat 1965-1967 do Mieczysława Gębarowicza oraz Tadeusza Kukiza z lat 1993-1996, opracowane przez Macieja Matwijowa. Korespondencja pochodzi ze zbiorów rękopiśmiennych Biblioteki Ossolineum we Wrocławiu. Cztery listy Aftanazego nadesłane do Gębarowicza, które znalazły się w niniejszym tomie, odsłaniają w niewielkim stopniu życie prywatne czy poglądy ich autora, a w nieco większym kulisy jego działalności naukowej związane z powstawaniem Dziejów rezydencji... Aftanazy dzielił się poglądami na temat środowiska ziemiańskiego, z którym próbował zawrzeć znajomość, 
oraz młodego, powojennego pokolenia. Odkrywał przed Gębarowiczem wygląd swojej „samotni” - wrocławskiego mieszkania, opisywał też spędzony za miastem urlop. W listach Aftanazego uwidaczniają się towarzyszące mu uczucia powątpiewania związane z sensem wydawania własnych publikacji. Dopingował natomiast swego lwowskiego mentora do napisania pamiętników. W korespondencji szczególnie wybrzmiewa atencja, chęć służenia pomocą czy rodzaj pewnego uniżenia Romana Aftanazego wobec dawnego lwowskiego dyrektora.

Pozostała część listów z ossolińskiego archiwum Gębarowicza z lat 1980-1982 pisanych ręką Aftanazego została wstrzymana przez polskie lub sowieckie organa bezpieczeństwa, z kolei część listów pisanych po wojnie zniszczył sam Aftanazy, gdy Mieczysław Gębarowicz nieopatrznie przekazał fragment swojej korespondencji do Ossolineum. Listy Aftanazego adresowane do Tadeusza Kukiza pochodzą natomiast z okresu, gdy Dzieje rezydencji zostały już wydane. Odsłaniają one w pewnym sensie naturę Aftanazego, który ujawniał swemu przyjacielowi sprzeciw wobec tytułowania jego osoby, niechęć do udzielania wywiadów czy awersję do nagród, zwłaszcza prestiżowych, które zdaniem Aftanazego przysporzyły mu więcej osób niechętnych czy wręcz wrogich. Pisał o swej samodzielności i wysiłku włożonym w pracę nad ostatnim z tomów Dziejów rezydencji..., przy doskwierającym mu słabnącym wzroku.

Trzecia część zbioru to wspomnienia bliskich przyjaciól, rodziny oraz współpracowników Aftanazego: Jana Kolasy, absolwenta prawa, przez krótki czas współpracownika Biblioteki Ossolineum we Wrocławiu (Migawki wspomnień), Ewy Biegun, córki Tadeusza Świerzawskiego, studenta Politechniki Wrocławskiej (Mój ojciec chrzestny), Teresy Wawrzyniakowej przez kilkanaście lat dzielącej wraz ze swoją rodziną i Aftanazym wspólne mieszkanie we Wrocławiu przy ul. Norwida 26 (Wspomnienie o przyjacielu), Jana Dowgiałło (Spadkobierca) oraz Andrzeja J. Baranowskiego, redaktora Materiałów do dziejów rezydencji (Cześć Jego pamięci). Przywołane reminiscencje ukazują Romana Aftanazego jako człowieka pełnego szacunku wobec innych osób, choć często nieprzystępnego, przyjaznego, ale tylko wobec tych, których darzył zaufaniem, pełnego pasji, poświęceń, uporu, ale też indywidualisty, ceniącego sobie własne zasady, jak również własną przestrzeń prywatną i naukową, człowieka precyzyjnie wytyczającego sobie cele, za to przygotowanego na wszelkie ewentualności, tęskniącego za utraconymi Kresami, choć sceptycznego co do ich powrotu do macierzy, wytrwałego turysty, kolekcjonera dzieł sztuki czy wreszcie samotnika skazującego samego siebie na samodzielność i samotność, zwłaszcza u kresu życia.

W części czwartej recenzowanego tomu znalazł się m.in. artykuł Jana K. Ostrowskiego, zatytułowany „Materiały” Romana Aftanazego i „Materiały do dziejów sztuki sakralnej". Autor wskazał na zależności między prowadzeniem badań nad sztuką kresową a sytuacją polityczną, nadmieniając również o możliwościach prowadzenia inwentaryzacji zabytków na Kresach. Jan K. Ostrowski przedstawił też w swoim tekście założenia badań sztuki sakralnej Kościoła rzymskokatolickiego na Kresach. Autor przyznał, że inspiracją w przeprowadzeniu jego projektu było właśnie dzieło Aftanazego, choć oba przedsięwzięcia różni metoda. Inwentaryzacja sztuki sakralnej możliwa była dzięki szeroko zakrojonym badaniom terenowym oraz kwerendzie ar- 
chiwalnej i bibliograficznej. Owocem wieloletnich badań stała się seria wydawnicza: Materiały do dziejów sztuki sakralnej, której już sam tytuł stanowi ukłon w stronę wielkiego „ossolińczyka” i jego monumentalnego dzieła.

Kolejny artykuł dotyczy Uroża (Uroż $w$ dawnym województwie ruskim). Jego autor, Stanisław Mossakowski w nawiązaniu do ósmego tomu Dziejów rezydencji na dawnych kresach Rzeczpospolitej, poświęconego ziemi przemyskiej i sanockiej ${ }^{4}$ (s. 252-257) przedstawił nowe badania związane z publikacją pamiętnika Janiny z Noskowskich Jarzymowskiej ${ }^{5}$, które uzupełniają informacje na temat ziemiańskiego życia w drewnianym dworze w Urożu przed pożarem w $1892 \mathrm{r}$.

Artykułem wieńczącym część czwartą, a zarazem cały tom, jest tekst Jana Dowgiałły pt. Erazm Sykst, luminarz lwowskiego Renesansu. Dwie postaci: siedemnastowiecznego lekarza, filozofa przyrody i działacza społecznego Syksta oraz historyka Aftanazego, Jan Dowgiałło połączył wspólnym miejscem urodzenia, wychowania oraz pracy. W swoim artykule autor przybliżył czytelnikowi zapomnianego przedstawiciela lwowskiej elity intelektualnej przełomu XVI i XVII w., który w istotny sposób wpłynął na rozwój hydrogeologii w Polsce.

Roman Aftanazy był i wciąż pozostaje inspiracją dla wielu badaczy. Postać wielkiego kustosza, wskrzeszona w niewielkim tomie wspomnień przez Zakład Narodowy im. Ossolińskich, wzbudza refleksję nad człowiekiem pełnym zaangażowania, imponującej wytrwałości i pasji. Ładnie wydaną książkę czyta się z przyjemnością, aczkolwiek lektura tomu Kustosz i samotnik może pozostawić czytelnika z niedosytem. Nie bardzo zrozumiałe są intencje redakcji, która zamieściła w książce poświęconej Romanowi Aftanazemu tekst Jana Dowgiałły o Erazmie Sykscie. Nasuwa się pytanie: czy ziemia lwowska jest wystarczającym argumentem, który spaja te dwie znamienite postaci? Podobnie, choć nieco mniejsze wątpliwości budzą zamieszczone w książce fotografie. Większość z nich niemal w ogóle nie przedstawia Romana Aftanazego, ale ilustruje m.in. zabezpieczenie Zakładu Narodowego we Lwowie w czasie wojny czy zniszczenia wojenne $w$ magazynach bibliotecznych. Tylko trzy zdjęcia ukazują samego Romana Aftanazego, jest też fotografia kartki $\mathrm{z}$ jego dziennika oraz karty ewakuacyjnej z 1946 r. Tomu Kustosz i samotnik nie opatrzono też indeksem osobowym czy geograficznym ani bibliografią, co utrudnia szybkie wyszukiwanie potrzebnych informacji.

Publikacja ma charakter popularnonaukowy. Redakcja nie sięgnęła do wywiadów, które za swojego życia udzielił Aftanazy, ani artykułów, które pojawiły się na jego temat, jak również recenzji jego dzieł. Nie ma więc tutaj tekstów, które omawiają i analizują znaczenie jego osiągnięć, jak również uwag polemicznych. Aftanazy został ukazany w książce przez pryzmat swojej pracy we Lwowie i Wrocławiu, niewiele natomiast znalazło się tutaj wątków z życia prywatnego.

Pomimo pewnych braków warto zapoznać się z wartościową i interesującą publikacją wydawnictwa Zakładu Narodowego im. Ossolińskich chociażby po to, by

${ }^{4}$ Id em, Dzieje rezydencji..., t. 8: Województwo ruskie, ziemia przemyska i sanocka, Wrocław 1996.

${ }^{5}$ J. Jarzymowska, Uroż, Dziadzio i wnuki. Opowieść prawdziwa, przedm., przyp. i objaśnienia historyczne S. Mossakowski, Warszawa 2015. 
poznać historię życia i pracy wielkiego „ossolińczyka” Romana Aftanazego, który dla wielu już naukowców był inspiratorem badań nad dziedzictwem kresowym, a dla jeszcze wielu innych może stać się odkryciem ${ }^{6}$.

\section{Bibliografia}

Aftanazy R., Materiały do dziejów rezydencji, t. 1-11, Warszawa 1986-1993.

Aftanazy R., Dzieje rezydencji na dawnych kresach Rzeczypospolitej, t. 1-11, Wrocław 1991-1997.

Epsztein T., Nieznane fakty z biografii Romana Aftanazego (1914-2004), „Studia Dziejów Rosji i Europy Środkowo-Wschodniej” 2015, t. 50, z. 2, s. 105-118.

J. Jarzymowska, Uroż, Dziadzio i wnuki. Opowieść prawdziwa, przedm., przyp. i objaśnienia historyczne S. Mossakowski, Warszawa 2015.

Wystarczy maszyna do pisania... Listy Romana Aftanazego do Wiktora Swiatelyka, oprac. W. Kudela-Świątek, „Krakowskie Pismo Kresowe” R. 2, 2010, s. 21-50.

${ }^{6}$ W drugim roczniku „Krakowskiego Pisma Kresowego” zamieściliśmy edycję wybranych listów Romana Aftanazego do ukraińskiego badacza, Wiktora Swiatełyka. Zob. Wystarczy maszyna do pisania... Listy Romana Aftanazego do Wiktora Swiatełyka, oprac. W. Kudela-S wiątek, „Krakowskie Pismo Kresowe" R. 2, 2010, s. 21-50 (przyp. red.). 